Bul. Agrohorti 3 (2) : 221 - 231 (2015)

\title{
Manajemen Pemupukan Kelapa Sawit (Elaeis guineensis Jacq.) di Perkebunan Kelapa Sawit, Kalimantan Barat
}

\author{
Fertilizer Management on Oil Palm Plantation, West Kalimantan
}

\author{
Ade Budiargo, Roedhy Poerwanto*, dan Sudradjat
}

\author{
Departemen Agronomi dan Hortikultura, Fakultas Pertanian, Institut Pertanian Bogor \\ (Bogor Agricultural University), Jl. Meranti, Kampus IPB Darmaga, Bogor 16680, Indonesia \\ Telp.\&Faks.62-251-8629353 e-mail agronipb@indo.net.id \\ "Penulis untuk korespondensi : roedhy8@yahoo.co.id
}

Disetujui 7 Mei 2015/ Published Online 15 Mei 2015

\begin{abstract}
The purpose of research are (1) to learn the technical and managerial aspects of oil palm plantation, (2) to study and analyze the management and fertilization efficiency of palm oil. The technical aspects that done during the research were participate in the plantation activity, i.e : fertilization, weed control, sanitation, leaf sampling, and harvesting. The managerial aspects that done during internship are become an assistant of foreman and assistant of field assistant. The observation done was observing the proper implementation of the rule of the fertilizer application in field. The observations indicated that the fertilizer application on the field has fulfilled these principles, although it could be better by improving the method and dosage aspects. The accuration of fertilization method was 85,4 \% for Urea and 80,6\% for Borate, but it can be improved by keeping the sanitation of palm oil circle and keeping the standart form and diameter of palm oil circle. Score of the precise of Urea dosage was 91,1\%, therefore the company should be use the standard measuring cup for each fertilizer. The precision of fertilizer types in the fertilizion has reached $100 \%$ for any types of fertilizer. The quantity of fertilizer that applicated in a year likely to affect in fresh fruit bunch production, but the fertilization have a positive correlation with the fresh fruit bunch production.Age and work experience of the fertilization labour doesn't have a real effect to their work performance. The efficiency of the employe use in the field has been reached with $0,1508 \mathrm{hk} \mathrm{ha} \mathrm{c}^{-1}$ employement index.
\end{abstract}

Keywords : fertilizer, fertilizer effectiveness, fertilizer efficiency, palm oil, production

\section{ABSTRAK}

Tujuan penelitian untuk (1) mempelajari aspek teknis dan manajerial perkebunan kelapa sawit, (2) mempelajari dan menganalisis manajemen dan efisiensi pemupukan kelapa sawit. Aspek teknis yang dilakukan selama kegiatan penelitian yaitu turut aktif dalam kegiatan perkebunan, antara lain : pemupukan, pengendalian gulma, sanitasi, LSU, dan panen. Aspek manajerial yang dilakukan yaitu dengan menjadi pendamping mandor dan pendamping asisten. Pengamatan dilakukan terhadap pengaplikasian pupuk di lapangan dengan mengamati pelaksanaan kaidah empat tepat. Hasil pengamatan menunjukkan bahwa aplikasi pemupukan di kebun telah memenuhi kaidah tersebut meskipun masih dapat ditingkatkan lagi pada aspek cara pemupukan dan ketepatan dosisnya. Nilai ketepatan cara pemupukan sebesar $85.4 \%$ untuk urea dan $80.6 \%$ untuk borat, hal tersebut dapat ditingkatkan dengan menjaga kebersihan piringan dan bentuk serta diameter piringan. Ketepatan dosis untuk pupuk urea $91.1 \%$ tetapi masih dapat ditingkatkan dengan mengganti takaran yang ada dengan takaran yang lebih sesuai. Ketepatan jenis pemupukan telah mencapai 100\% untuk semua jenis pupuk sesuai rekomendasi. Jumlah pupuk yang diaplikasi dalam setahun cenderung berpengaruh nyata terhadap produksi TBS, dan berkorelasi positif terhadap produksi TBS. Usia dan pengalaman kerja pemupuk tidak berpengaruh nyata terhadap prestasi kerja yang didapatkan. Efisiensi dalam penggunaan tenaga kerja di perkebunan ini telah tercapai dengan Indeks Tenaga Kerja sebesar $0.1508 \mathrm{Hk} \mathrm{Ha}^{-1}$.

Kata kunci : efektivitas pemupukan, efisiensi pemupukan, kelapa sawit, produksi, pupuk 


\section{PENDAHULUAN}

Kelapa sawit (Elaeis guineensis Jacq.) merupakan tanaman penghasil minyak nabati yang memiliki keunggulan lebih jika dibandingkan dengan tanaman penghasil minyak nabati yang lain, yaitu memiliki produktivitas yang tinggi mencapai 4 ton ha $^{-1}$ Crude Palm Oil (CPO), umur ekonomis yang panjang dan mudah beradaptasi dengan lingkungannya. Minyak kelapa sawit juga merupakan bahan baku pembuatan bahan pangan maupun non pangan, dan bahan bakar yang dapat diperbaharui (renewable).

Indonesia merupakan salah satu negara produsen kelapa sawit yang terus berkembang. Perkembangan luas dan produksi perkebunan kelapa sawit di Indonesia selama sepuluh tahun terakhir terus meningkat hingga mencapai 10.01 juta hektar pada tahun 2013 dan merupakan perkebunan kelapa sawit yang terluas di dunia. Demikian pula produksinya pada tahun 2013 mencapai 27.74 juta ton dengan produktivitas $3855 \mathrm{~kg} \mathrm{ha}^{-1}$ dan menduduki posisi pertama di dunia melampaui Malaysia (Ditjenbun, 2013).

Pemupukan kelapa sawit bertujuan untuk menambah unsur-unsur hara yang kurang atau tidak tersedia didalam tanah, yang mana unsur hara tersebut diperlukan oleh tanaman untuk pertumbuhan vegetatif dan generatif agar didapatkan tandan buah segar yang optimal. Menurut Sutarta dan Winanrna (2002) pemupukan merupakan suatu upaya untuk menyediakan unsur hara yang cukup guna mendorong pertumbuhan vegetatif yang sehat dan produksi TBS hingga mencapai produktivitas maksimum.

Pemupukan merupakan faktor yang sangat penting untuk meningkatkan produksi. Biaya yang dikeluarkan untuk pemupukan berkisar antara 40$60 \%$ dari biaya pemeliharaan tanaman secara keseluruhan atau sekitar $24 \%$ dari total biaya produksi. Pemupukan pada tanaman kelapa sawit harus dapat menjamin pertumbuhan vegetatif dan generatif yang normal sehingga dapat memberikan produksi Tandan Buah Segar (TBS) yang optimal serta menghasilkan minyak sawit mentah yang tinggi baik kualitas maupun kuantitas (Adiwiganda, 2007).

Efektivitas pemupukan berhubungan dengan persentase hara pupuk yang diserap tanaman. Pemupukan dikatakan efektif jika sebagian besar hara pupuk diserap tanaman sedangkan efisiensi pemupukan berkaitan dengan hubungan antara biaya (bahan pupuk, alat kerja, dan upah) dengan tingkat produksi yang dihasilkan. Agar kebutuhan tanaman atas unsur hara dapat tercukupi dengan tepat maka sebelum diadakan pemupukan terlebih dahulu perlu analisis kebutuhan unsur hara tanaman tersebut melalui analisis tanah dan daun (Pahan 2008).

Pemupukan yang efektif dan efisien dapat dicapai jika dilakukan dengan tepat jenis dan dosis pupuk, cara pemberian pupuk, waktu pemupukan, tempat aplikasi, dan pengawasan dalam pelaksanaan pemupukan. Pemupukan merupakan salah satu faktor penting yang berperan untuk mencapai produktivitas yang tinggi, terutama dalam memenuhi persyaratan unsur hara (Poeloengan et al. 2003). Aspek manajemen pemupukan juga penting untuk dipelajari agar pelaksanaan pemupukan sesuai dengan standar operasional baku yang dijalankan oleh suatu perusahaan sehingga penggunaan pupuk efektif dan efisien. Penelitian bertujuan mempelajari aspek teknis dan manajerial perkebunan kelapa sawit serta menganalisis manajemen dan efisiensi pemupukan kelapa sawit.

\section{METODE PENELITIAN}

Kegiatan penelitian ini dilaksanakan di Perkebunan Kelapa Sawit, Kalimantan Barat. Dimulai pada bulan Februari hingga Juni 2014. Penelitian yang dilakukan meliputi kegiatan teknis di lapangan dan kegiatan manajerial baik di perkebunan maupun di kantor. Teknis di lapang untuk turut aktif dalam pelaksanaan kegiatan kebun, wawancara, dan diskusi dengan mandor maupun dengan para staf. Kegiatan yang dilakukan adalah sebagai karyawan harian lepas (KHL) selama satu bulan, kemudian sebagai pendamping mandor selama satu bulan dan asisten selama dua bulan. Kegiatan teknis lapang yang penulis lakukan yaitu kegiatan di pembibitan, pengendalian gulma, pemupukan, dan panen. Aspek manajerial penulis dapatkan pada saat menjadi pendamping mandor dan pendamping asisten serta berkonsultasi dengan manajer selama pelaksaan penelitian.

\section{Pengumpulan Data dan Informasi}

Pengumpulan data yang dilakukan oleh penulis meliputi pengambilan data primer dan data sekunder. Data primer merupakan informasi yang diperoleh secara langsung melalui pengamatan yang 
dilakukan oleh penulis di lapangan maupun diskusi langsung dengan KHL, mandor dan asisten kebun. Data primer meliputi efektivitas pemupukan (tepat waktu, dosis, jenis dan cara), efisiensi pemupukan (efisiensi waktu dan tenaga kerja).

Data sekunder diperoleh dari data kebun yang diberikan oleh kasi administrasi kebun dan studi pustaka. Data sekunder yang diperoleh yaitu data curah hujan, rekomendasi pemupukan 20102014, struktur organisasi, data ketenagakerjaan, peta area, historis pemupukan dan historis produksi. Data yang diperoleh kemudian dianalisis dengan metode deskriptif kualitatif. Data primer yang diamati, meliputi:

1. Ketepatan cara pemupukan. Data ini diperoleh dengan mengukur jarak penaburan pupuk yang terdekat dari batang tanaman kelapa sawit kemudian dibandingkan dengan standar perusahaan. Pengambilan contoh dilakukan terhadap 8 penabur (setiap penabur diambil sample sebanyak 10 tanaman) dengan tiga kali ulangan.

2. Ketepatan dosis pupuk. Pengamatan dilakukan terhadap dosis per tanaman, pengamatan ketepatan dosis eceran dilakukan dengan menghitung jumlah tanaman per pasar pikul / dua jalur tanaman sampai dengan jalan kontrol. Jumlah tanaman per pasar pikul tersebut kemudian dibandingkan dengan dosis per tanaman dan jumlah pupuk yang di ecer. Jumlah pasar pikul yang diambil sebanyak 15 pasar pikul yang diambil secara acak terurut pada 2 blok. Pengamatan juga dilakukan terhadap ketepatan dosis per tanaman dengan menghitung jumlah taburan per tanaman. Pengambilan contoh tanaman dilakukan terhadap 5 orang penabur dengan tiga kali ulangan. Masing-masing penabur diambil 10 contoh tanaman yang diamati.

3. Ketepatan jenis pupuk. Data ini diperoleh dengan pengamatan realisasi jenis pupuk yang diaplikasikan dilapangan kemudian dibandingkan dengan rekomendasi yang diberikan oleh Departemen Riset.

4. Ketepatan waktu pemupukan. Pengamatan dilakukan terhadap realisasi waktu pemupukan yang diaplikasikan di lapangan kemudian dibandingkan dengan rekomendasi waktu pemupukan yang diberikan oleh Departemen Riset serta pola curah hujan selama periode waktu tertentu dilaksanakannya pemupukan.

5. Efisisensi tenaga kerja dan Prestasi kerja penabur. Data ini diperoleh melalui pengamatan jumlah pupuk yang diecer ke lahan dan diaplikasi, jumlah penabur, luas yang teraplikasi, serta waktu dalam menyelesaikannya yang kemudian dibandingkan dengan standar perusahaan.

\section{HASIL DAN PEMBAHASAN}

\section{Keefektifan Pemupukan dengan Prinsip Empat Tepat}

Tepat Jenis. Jenis pupuk yang diaplikasikan di perkebunan ini sudah sesuai dengan rekomendasi yang diperoleh dari kantor pusat. Jenis pupuk yang digunakan dapat dilihat pada Tabel 1. Tabel tersebut menunjukkan jenis pupuk yang digunakan pada tahun 2013/2014. Pupuk yang digunakan merupakan pupuk tunggal dengan unsur hara utama $\mathrm{N}, \mathrm{P}, \mathrm{K}, \mathrm{Mg}$, dan Ca. Sedangkan pupuk Borat digunakan untuk memenuhi kebutuhan hara mikro B. Setiap jenis dan jumlah pupuk yang diaplikasikan harus sesuai dengan rekomendasi yang dikeluarkan oleh Agronomy Support Departemen. Jenis pupuk yang digunakan di kebun pada tahun 2013/2014 adalah pupuk tunggal dengan pertimbangan harga yang lebih murah dan ketepatan dosis dalam aplikasinya lebih tinggi sehingga kebutuhan hara tanaman akan terpenuhi. Poeloengan et al. (2003) menyatakan bahwa beberapa hal yang menjadi dasar pertimbangan dalam penentuan jenis pupuk antara lain : umur tanaman, gejala defisiensi hara, kondisi lahan, dan harga pupuk. 
Tabel 1. Jenis pupuk yang digunakan di salah satu perkebunan kelapa sawit di Kalimantan Barat tahun $2013 / 2014$

\begin{tabular}{|c|c|c|c|c|}
\hline Unsur Hara & Jenis Pupuk & Rumus Kimia & Hara Utama & Kelarutan dalam air \\
\hline Nitrogen $(\mathrm{N})$ & Urea & $\left(\mathrm{NH}_{2}\right)_{2} \mathrm{CO}$ & $46 \% \mathrm{~N}$ & Mudah Larut \\
\hline Kalium $(\mathrm{K})$ & MOP & $\mathrm{KCl}$ & $\begin{array}{l}60 \% \mathrm{~K}_{2} \mathrm{O} \\
45 \% \mathrm{Cl}\end{array}$ & Dapat Larut \\
\hline Fosfor $(\mathrm{P})$ & $\mathrm{RP}$ & $\mathrm{Ca}_{3}\left(\mathrm{H}_{2} \mathrm{PO}_{4}\right)_{2}$ & $33 \% \mathrm{P}_{2} \mathrm{O}_{5}$ & Sangat Rendah \\
\hline Magnesium (Mg) & Kieserit & $\mathrm{MgSO}_{4} \cdot \mathrm{H}_{2} \mathrm{O}$ & $\begin{array}{l}26 \% \mathrm{MgO} \\
21 \% \mathrm{~S}\end{array}$ & Dapat Larut \\
\hline & Dolomit & $\mathrm{CaMg}\left(\mathrm{CO}_{3}\right)_{2}$ & $\begin{array}{l}22 \% \mathrm{MgO} \\
40 \% \mathrm{CaO}\end{array}$ & Sukar Larut \\
\hline Boron (B) & Borat & $\mathrm{B}_{2} \mathrm{O}_{3}$ & $\begin{array}{l}46 \% \mathrm{~B}_{2} \mathrm{O}_{3} \\
20 \% \mathrm{Na}_{2} \mathrm{O} \\
0,02 \% \mathrm{SO}_{4}\end{array}$ & Sukar Larut \\
\hline
\end{tabular}

Sumber : Data salah satu kebun kelapa sawit di Kalimantan Barat Tahun 2014

Dosis rekomendasi pemupukan diperoleh setelah dilakukan kegiatan pengambilan kesatuan contoh daun atau Leaf Sampling Unit (LSU). Contoh daun yang diperoleh dari LSU kemudian dikeringkan dan dikirim ke laboratorium untuk menganalisis jumlah kandungan setiap unsur hara yang terdapat dalam daun. Dari data kandungan unsur hara tersebut maka dapat diketahui unsur hara apa saja yang kurang dan perlu ditambah agar produksi dapat maksimal. Jumlah unsur hara yang terkandung didalam daun tersebut kemudian dibandingkan dengan kebutuhan tanaman kelapa sawit. Misalnya, kandungan unsur $\mathrm{N}$ pada daun berada dalam keadaan kritis jika jumlahnya $<2.3 \%$ dan akan optimal jika jumlahnya $2.8 \%$. Oleh karena itu agar produksi dapat maksimal maka unsur $\mathrm{N}$ yang harus ditambah adalah $0.5 \%$. Data tersebut kemudian diolah oleh Departemen Riset dan dikonversikan menjadi dosis rekomendasi pemupukan.

Tabel 2. Realisasi pemupukan salah satu perkebunan kelapa sawit di Kalimantan Barat tahun 2013/2014

\begin{tabular}{clccccc}
\hline \multirow{2}{*}{$\begin{array}{c}\text { Unsur } \\
\text { hara }\end{array}$} & \multicolumn{1}{c}{ Jenis pupuk } & Rekomendasi & \multicolumn{2}{c}{ Realisasi } & Total realisasi & \multirow{2}{*}{ \% Realisasi } \\
\cline { 3 - 4 } & (ton) & Rotasi 1 (ton) & Rotasi 2 (ton) & (ton) & \\
\hline $\mathrm{N}$ & Urea & 1463.1 & 929.1 & 534.1 & 1463.2 & 100.01 \\
$\mathrm{P}$ & Rock Phospate (RP) & 1581.7 & 1249.8 & 361.9 & 1611.7 & 101.90 \\
$\mathrm{~K}$ & MOP & 1230.4 & 723.2 & 506.6 & 1229.8 & 99.95 \\
$\mathrm{Mg}$ & Kiserit & 490.2 & $490.3^{*}$ & - & 490.3 & 100.02 \\
$\mathrm{~B}$ & Dolomit & 171.1 & $171.1^{*}$ & - & 171.1 & 100.00 \\
& Borat & 66.2 & - & $67.2^{*}$ & 67.2 & 101.51 \\
\hline
\end{tabular}

Sumber : Data kebun salah satu perkebunan kelapa sawit di Kalimantan Barat

Keterangan : *Pemupukan satu kali dalam setahun

Tabel diatas menunjukkan bahwa rekomendasi pemupukan salah satu perkebunan kelapa sawit di Kalimantan Barat tahun 2013/2014 telah terealisasi sebesar $100.56 \%$ dari rekomendasi. Jumlah realisasi pemupukan di perkebunan lebih banyak daripada jumlah rekomendasi, ini disebabkan karena kebijakan kebun agar semua pupuk yang ada di gudang diaplikasikan tanpa terkecuali. Hal ini menunjukkan bahwa semua jenis pupuk yang direkomendasikan oleh Departemen Riset telah diaplikasikan, sehingga pemupukan di perkebunan ini telah memenuhi kaidah tepat jenis.
Tepat Waktu. Pemupukan di perkebunan kelapa sawit ini dilaksanakan dalam dua rotasi, rotasi pertama dilaksanakan pada bulan JuniNovember dan rotasi kedua dilaksanakan pada bulan Desember-Mei setiap tahunnya. Interval waktu yang diberikan antara rotasi pertama dengan rotasi kedua dimaksudkan agar tidak terjadi jarak yang terlalu jauh antara pemupukan yang terakhir dilakukan pada rotasi kedua dengan pemupukan rotasi pertama pada tahun berikutnya. Apabila rotasi keduanya diaplikasikan secara bersamaan (misalnya pada rotasi pertama), kemudian interval antara 
rotasi terakhir dengan rotasi pertama pada tahun berikutnya menjadi jauh, kondisi tersebut akan berpengaruh tehadap pertumbuhan dan produksi tanaman kelapa sawit. Kondisi tersebut penting terutama pada kasus pupuk yang memiliki tingkat residu rendah seperti Nitrogen (Urea) atau pupuk yang cepat larut (MOP dan Kieserit) yang cenderung tercuci sehingga menyebabkan kehilangan secara nyata. Waktu dan frekuensi pemupukan ditentukan oleh iklim (terutama curah hujan), sifat fisik tanah, ketersediaan pupuk, serta adanya sifat sinergis dan antagonis antar unsur hara (Pahan, 2007).

Pertimbangan aplikasi pupuk yang diterapkan di Kebun BKE adalah berdasarkan interaksi antar jenis pupuk. Pupuk yang bersifat sinergis seperti Urea (unsur hara $\mathrm{N}$ ) dengan pupuk MOP (unsur hara K) dapat diaplikasikan secara bersamaan karena tidak akan terjadi reaksi antara kedua pupuk tersebut. Sedangkan untuk pupukpupuk yang bersifat antagonis misalnya Urea (unsur hara $\mathrm{N}$ ) dengan RP (unsur hara $\mathrm{P}$ ), Urea (unsur hara $\mathrm{N}$ ) dengan Kieserit (unsur hara $\mathrm{Mg}$ ), atau MOP (unsur hara $\mathrm{K}$ ) dengan Kieserit (unsur hara $\mathrm{Mg}$ ) tidak dapat diaplikasikan dalam waktu kurang dari empat minggu. Pemberian $\mathrm{P}$ yang lebih awal akan memberikan energi untuk tanaman karena $P$ merupakan sumber energi yang akan merubah ADP menjadi ATP melalui proses fotosintesis. Selain itu pemberian $\mathrm{P}$ yang lebih awal juga dapat meningkatkan KTK tanah sehingga daya serap tanah terhadap unsur $\mathrm{K}$ dan $\mathrm{Mg}$ meningkat. Oleh karena itu, urutan pemupukan yang disarankan adalah P-N-Mg-K (Winarna et al. 2003).

Manfaat pemupukan yang maksimum dapat tercapai pada curah hujan antara $100-250 \mathrm{~mm}$ per bulan. Pada masa ini, kondisi tanah cukup basah (tetapi belum jenuh) sehingga memudahkan terserapnya unsur hara oleh tanaman. Apabila curah hujan $<100 \mathrm{~mm}$ per bulan, sebaiknya tidak dilakasanakan pemupukan Urea karena memiliki potensi penguapan yang tinggi. Sedangkan jika curah hujan $>250 \mathrm{~mm}$ per bulan, sebaiknya pupuk yang mudah larut (Urea dan MOP) tidak diaplikasikan karena berpotensi kehilangan pupuk akibat aliran permukaan dan erosi tanah, terutama pada lahan dengan kemiringan yang cukup tinggi.

Tabel 3. Realisasi pemupukan di salah satu perkebunan kelapa sawit di Kalimantan Barat tahun 2013/2014

\begin{tabular}{lcccccccccccc}
\hline Jenis & \multicolumn{10}{c}{} & \multicolumn{10}{c}{ Bulan } \\
\cline { 2 - 8 } & Jun & Jul & Ags & Sep & Okt & Nov & Des & Jan & Feb & Mar & Apr & Mei \\
\hline Urea & I & I & I & I & - & - & II & - & - & II & II & II \\
RP & - & - & I & I & I & I & II & II & - & - & II & II \\
MOP & - & I & - & I & I & I & II & II & - & - & II & II \\
Kies & - & - & - & - & - & - & - & - & V & V & - & V \\
Dol & - & - & - & - & - & - & - & - & V & V & V & - \\
Borat & - & - & - & - & - & - & - & - & - & - & V & V \\
\hline
\end{tabular}

Sumber : Kantor salah satu perkebunan kelapa sawit di Kalimantan Barat, 2014

Keterangan : I = Aplikasi pupuk rotasi pertama; II = Aplikasi pupuk rotasi kedua; $\mathrm{V}=$ Aplikasi pupuk hanya sekali setahun

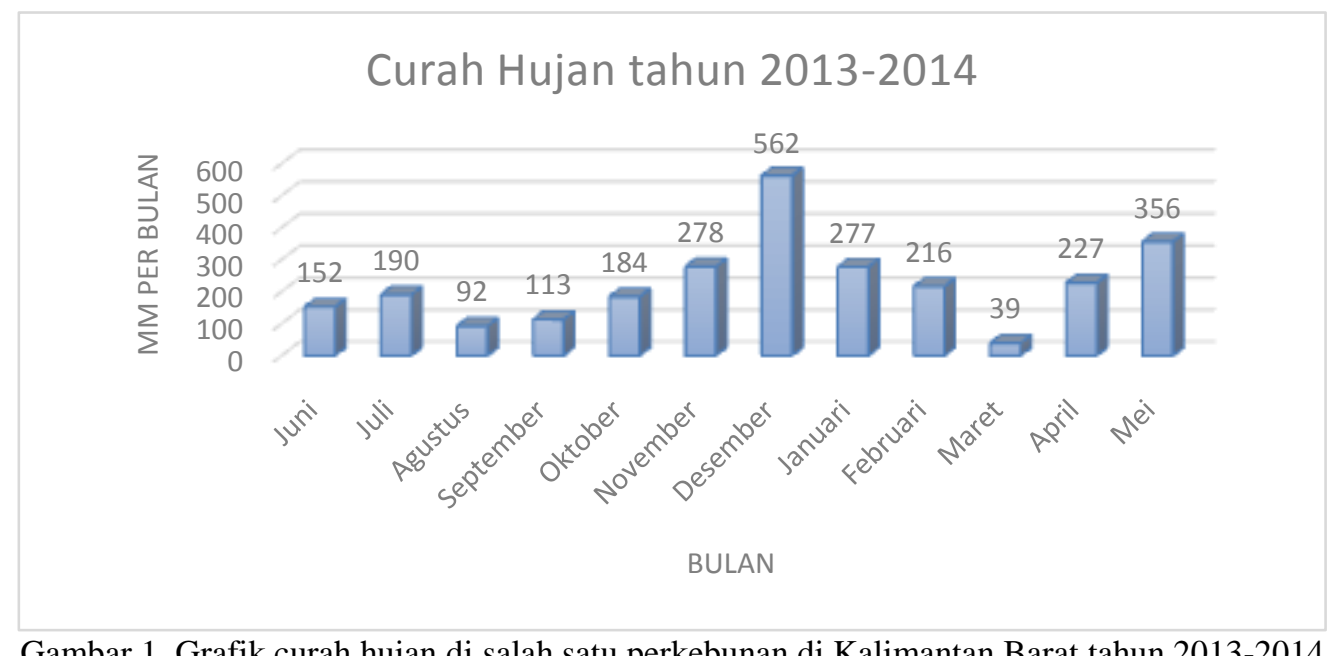

Gambar 1. Grafik curah hujan di salah satu perkebunan di Kalimantan Barat tahun 2013-2014 
Berdasarkan Tabel realisasi pemupukan di Kebun selama satu tahun terakhir, terlihat bahwa aplikasi pemupukan dilakukan disetiap bulan mulai dari bulan Juni 2013-Mei 2014. Sedangkan berdasarkan Grafik curah hujan diatas, dapat dilihat bahwa puncak musim hujan terjadi pada bulan Desember 2013, dan bulan terkering terjadi pada bulan Maret 2014.

Hasil pemupukan yang terbaik akan didapat jika pemupukan dilaksanakan pada curah hujan antara 100-250 mm per bulan. Pemupukan tetap dilaksanakan pada curah $>250 \mathrm{~mm}$ per bulan yaitu pada bulan November, Desember, Januari dan Mei dengan curah hujan 278, 562, 277 dan $356 \mathrm{~mm}$ per bulan. Hal ini sangat disayangkan karena pupuk yang diaplikasikan pada bulan tersebut termasuk pupuk Urea dan MOP yang rentan terhadap pencucian oleh air hujan. Pada bulan terkering yaitu bulan Maret 2014 dengan curah hujan yang hanya $39 \mathrm{~mm}$ per bulan juga tetap dilakukan pemupukan untuk pupuk Urea, Kieserit dan Dolomit. Untuk pupuk Urea sebaiknya tidak dilakukan pemupukan pada bulan kering, karena pupuk Urea sangat cepat untuk menguap.

Waktu pemupukan yang tepat idealnya dilakukan saat menjelang musim hujan dan di akhir musim hujan, namun pada Tabel menunjukkan kegiatan pemupukan dilaksanakan setiap bulan. Hal ini disebabkan karena aplikasi pupuk di kebun tidak hanya menyesuaikan dengan curah hujan, tetapi juga harus menyesuaikan dengan ketersediaan pupuk di gudang karena sering kali suplier pupuk terlambat dalam mendistribusikan pupuk sampai ke kebun dikarenakan kondisi cuaca yang tidak mendukung. Oleh karena itu konsep pemupukan tepat waktu belum terlaksana dengan baik, hal ini perlu diperhatikan oleh perusahaan mengingat biaya yang dibutuhkan untuk pemupukan sangat besar. Pemupukan yang tepat waktu akan meningkatkan keefektifan penyerapan unsur hara dan efisiensi biaya.

Tabel 4. Ketepatan eceran salah satu perkebunan di Kalimantan Barat

\begin{tabular}{cccccc}
\hline \multirow{2}{*}{ No. Gawangan } & Jumlah pokok/pasar sampai kontrol & Dosis (Kg/pokok) & \multicolumn{2}{c}{ \% Ketepatan } \\
\cline { 3 - 5 } & Blok G22 & Blok F20 & & Blok G22 & Blok F20 \\
\hline 2 & 33 & 28 & 1.5 & 101.01 & 119.05 \\
8 & 34 & 29 & 1.5 & 98.04 & 114.94 \\
10 & 37 & 30 & 1.5 & 90.09 & 111.11 \\
14 & 36 & 31 & 1.5 & 92.59 & 107.53 \\
18 & 37 & 32 & 1.5 & 90.09 & 104.17 \\
22 & 38 & 32 & 1.5 & 87.72 & 104.17 \\
26 & 37 & 31 & 1.5 & 90.09 & 107.53 \\
30 & 38 & 29 & 1.5 & 87.72 & 114.94 \\
34 & 38 & 32 & 1.5 & 87.72 & 104.17 \\
38 & 38 & 30 & 1.5 & 87.72 & 111.11 \\
42 & 37 & 32 & 1.5 & 90.09 & 104.17 \\
46 & 38 & 31 & 1.5 & 87.72 & 107.53 \\
50 & 36 & 30 & 1.5 & 92.59 & 111.11 \\
54 & 35 & 28 & 1.5 & 95.24 & 119.05 \\
Rata-rata: & 23 & 30 & 1.5 & 144.93 & 111.11 \\
& 35.67 & 30.33 & 1.5 & 94.89 & 110.11 \\
\hline
\end{tabular}


Tepat Dosis. Kebutuhan pupuk setiap lokasi berbeda-beda tergantung dari kondisi topografi lokasi tersebut. Pengeceran adalah salah satu kunci untuk mendapatkan dosis aplikasi yang sesuai dengan rekomendasi. Pengamatan ketepatan dosis eceran dilakukan karena pemupukan di kebun tidak menggunakan sistem untilan. Eceran yang digunakan tetap menggunakan karung $50 \mathrm{~kg}$. Pengamatan yang dilakukan dengan mengamati jumlah tanaman sawit pada 15 pasar pikul atau dua jalur tanaman sampai dengan jalan kontrol dan diambil secara acak. Pengamatan dilakukan pada dua blok yaitu blok G22 dan F20 yang dipupuk dengan dosis $1.5 \mathrm{~kg}$ per pokok. Ketepatan eceran rata-rata pada blok G22 yang didapatkan sebesar $94.89 \%$, sedangkan pada blok F20 sebesar $110.11 \%$ dan ketepatan pengeceran rata-rata pada kedua blok adalah $102.50 \%$. Penyebab adanya perbedaan ketepatan pada kedua blok tersebut karena jumlah pokok sawit pada setiap pasar pikul, pada blok G22 rata-rata jumlah tanaman per pasar pikul sampai dengan jalan kontrol adalah 35.67 pokok sedangkan pada blok F20 adalah 30.33 pokok. Jika dihitung dengan standar eceran $50 \mathrm{~kg}$ dan dosis $1.5 \mathrm{~kg} /$ pokok, maka akan didapatkan ketepatan dosis optimal untuk 33.33 tanaman. Pengeceran yang dilakukan di perkebunan kelapa sawit ini sudah sangat baik. Namun, masih perlu perhatian pada saat pengeceran di areal yang berparit, karena ada atau tidaknya akses akan sangat mempengaruhi ketepatan pengeceran. Oleh karena itu, untuk mendapatkan ketepatan dosis yang optimal sebaiknya pemupukan dilakukan dengan sistem untilan (Pahan, 2007).

Pengamatan ketepatan dosis taburan pupuk Urea dilakukan di tiga blok F8, F14, dan F15. Penaburan pupuk dilakukan oleh karyawan dengan menggunakan mangkuk atau cepuk yang terbuat dari stainless dan sudah dikalibrasi terhadap setiap jenis pupuk, sehingga terdapat standarisasi takaran penaburan. Hal ini ditujukan untuk meminimalisir kekurangan maupun kelebihan dosis dalam penaburan pupuk. sehingga untuk dosis $1 \mathrm{~kg}$ per tanaman dibutuhkan pupuk sebanyak dua cepuk. Apabila dalam penaburan pupuk kurang dari dua cepuk maka terjadi kekurangan dosis, sebaliknya jika taburan melebihi dua cepuk maka terjadi kelebihan dosis pemupukan.

Prinsip utama dalam penaburan (aplikasi) pupuk yaitu pemberian pupuk pada setiap pokok harus sesuai dosis yang ditentukan dalam buku rekomendasi pemupukan, dosis tersebut merupakan hasil analisis daun dan analisis produksi. Oleh karena itu, ketepatan dan ketelitian aplikasi pupuk harus menjadi pedoman dalam pelaksanaan pemupukan.

Tabel 5. Pengamatan ketepatan dosis taburan pupuk salah satu perkebunan kelapa sawit di Kalimantan Barat

\begin{tabular}{|c|c|c|c|c|c|c|c|c|c|c|}
\hline Blok & $\begin{array}{c}\text { Jenis } \\
\text { Pupuk }\end{array}$ & Dosis & Penabur & $\begin{array}{c}\text { Jumlah } \\
\text { Tanaman }\end{array}$ & TTD & TKD & TLD & $\% \mathrm{TD}$ & $\% \mathrm{KD}$ & $\% \mathrm{LD}$ \\
\hline \multirow[t]{5}{*}{ F8 } & Urea & 1 & 1 & 90 & 82 & 6 & 2 & 91.1 & 6.7 & 2.2 \\
\hline & & & 2 & 90 & 79 & 5 & 6 & 87.8 & 5.5 & 6.7 \\
\hline & & & 3 & 90 & 71 & 4 & 15 & 78.9 & 4.4 & 16.7 \\
\hline & & & 4 & 90 & 81 & 5 & 4 & 90.0 & 5.6 & 4.4 \\
\hline & & & 5 & 90 & 88 & 1 & 1 & 97.8 & 1.1 & 1.1 \\
\hline \multirow[t]{5}{*}{ F14 } & Urea & 1 & 1 & 90 & 73 & 9 & 8 & 81.1 & $1 ., 0$ & 8.9 \\
\hline & & & 2 & 90 & 85 & 2 & 3 & 94.4 & 2.3 & 3.3 \\
\hline & & & 3 & 90 & 79 & 4 & 7 & 87.8 & 4.4 & 7.8 \\
\hline & & & 4 & 90 & 86 & 3 & 1 & 95.6 & 3.3 & 1.1 \\
\hline & & & 5 & 90 & 89 & 1 & 0 & 98.9 & 1.1 & 0.0 \\
\hline \multirow[t]{6}{*}{ F15 } & Urea & 1 & 1 & 90 & 81 & 6 & 3 & 90.0 & 6.7 & 3.3 \\
\hline & & & 2 & 90 & 83 & 5 & 2 & 92.2 & 5.6 & 2.2 \\
\hline & & & 3 & 90 & 77 & 4 & 9 & 85.6 & 4.4 & 10.0 \\
\hline & & & 4 & 90 & 87 & 2 & 1 & 96.7 & 2.2 & 1.1 \\
\hline & & & 5 & 90 & 89 & 0 & 1 & 98.9 & 0.0 & 1.1 \\
\hline & & & \multicolumn{2}{|c|}{ Rata-rata } & & & & 91.1 & 4.2 & 4.7 \\
\hline
\end{tabular}

Keterangan $:$ TTD = Tanaman Tepat Dosis; TKD = Tanaman Kurang Dosis; TLD = Tanaman Lebih Dosis; TD = Tepat Dosis 
Berdasarkan data pengamatan pada tabel diatas, didapatkan rata-rata ketepatan dosis taburan untuk pemupukan Urea dengan dosis $1 \mathrm{~kg}$ adalah sebesar $91.1 \%$. Hasil tersebut sudah baik, akan tetapi masih dibawah standar yang ditetapkan oleh perusahaan 95-100\% untuk ketepatan dosis. Untuk tanaman yang mendapatkan dosis taburan yang lebih dari rekomendasi rata-rata sebanyak 4.7\% sedangkan tanaman yang mengalami kekurangan dosis rata-rata sebanyak $4.2 \%$. Dari angka-angka tersebut dapat dikatakan bahwa ketepatan dosis pemupukan di perkebunan kelapa sawit ini hampir memenuhi kaidah tepat dosis dalam penaburannya. Hal yang membatasi ketepatan dosis sehingga kurang maksimal adalah penggunaan cepuk yang kurang sesuai jika digunakan untuk pupuk Urea. Hal ini disebabkan karena berat jenis pupuk Urea lebih rendah jika dibandingkan dengan pupuk Kieserit, sehingga jika ditimbang seberat $0.5 \mathrm{~kg}$ maka seakan-akan jumlah pupuknya akan lebih banyak jika dibandingkan dengan Kieserit. Oleh karena itu, untuk mendapatkan ketepatan dosis yang optimal maka sebaiknya menggunakan cepuk yang sesuai untuk masing-masing jenis pupuk.

Tepat Cara. Menurut Lubis (2008), penaburan pupuk dengan radius $2 \mathrm{~m}$ atau pada pelepah dan berbentuk "U-Shape" dilakukan karena akar tertier dan kuarter yang aktif menyerap hara lebih banyak berada dibawah pelepah dan gawangan mati dibanding pada piringan. Cara menempatkan pupuk yang akan diaplikasikan sangat mempengaruhi presentase unsur hara yang dapat diserap oleh akar tanaman. Penempatan / aplikasi yang tepat dapat menambah kapasitas bawa (carrying capacity) pupuk dapat ditingkatkan. Cara pengaplikasian pupuk yang digunakan di perkebunan kelapa sawit ini sesuai dengan standar yang ditetapkan oleh perusahaan, yaitu: untuk pupuk Urea dan Borat ditabur merata pada bidang piringan, untuk pupuk MOP ditabur $40 \%$ di bidang piringan dan $60 \%$ diluar bidang piringan, dan untuk pupuk RP, Kieserit, dan Dolomit ditabur merata pada gawangan mati. Cara pemupukan yang dianjurkan oleh PPKS adalah dengan menabur pupuk $(\mathrm{P}, \mathrm{K}, \mathrm{Mg})$ secara merata di piringan pada jarak $1.5 \mathrm{~m}$ dari pangkal batang ke arah luar piringan, sedangkan pupuk $\mathrm{N}$ dianjurkan agar dibenam dalam tanah (PPKS, 2003).

Data ketepatan cara diperoleh dengan mengukur jarak terdekat antara taburan pupuk dari pokok sawit. Setiap penabur diambil 10 tanaman contoh yang diambil secara acak dengan 3 kali ulangan. Data tersebut kemudian dibandingkan dengan standar taburan yang ditetapkan oleh perusahaan dan ditampilkan dalam bentuk persentase ketepatan cara. Pengamatan hanya dilakukan pada pupuk Urea dan Borat karena kedua pupuk tersebut harus diaplikasikan pada bidang piringan. Hasil pengamatan ketepatan cara aplikasi oleh penabur dapat dilihat pada Tabel 6 .

Tabel 6. Ketepatan cara aplikasi pupuk oleh penabur

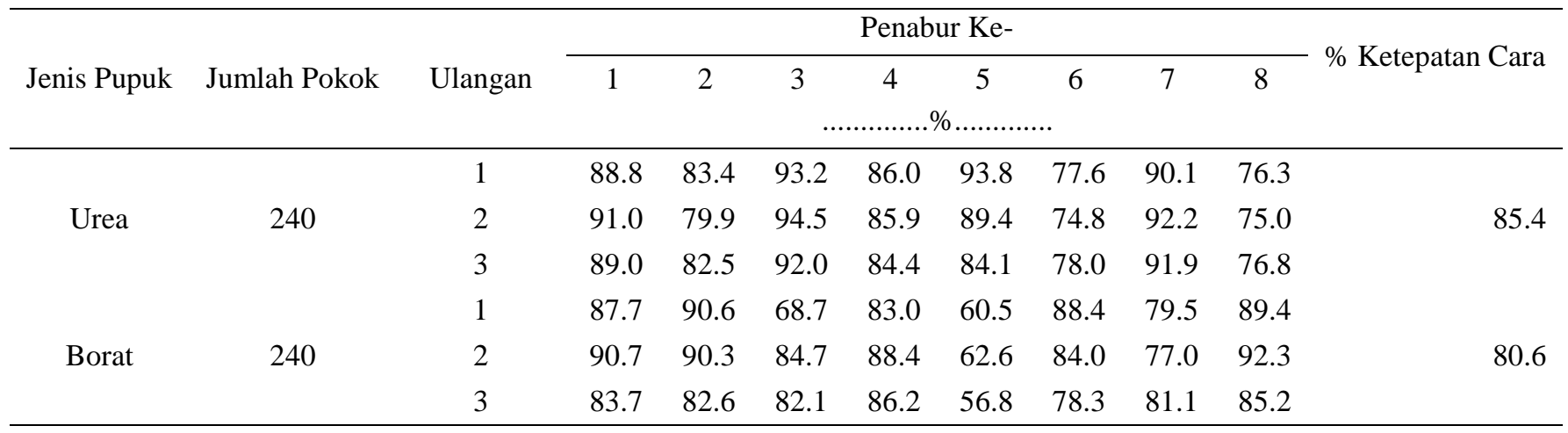

Tabel diatas menunjukkan rata-rata ketepatan cara para penabur untuk masing-masing pupuk cukup baik yaitu $85.4 \%$ untuk pupuk Urea dan $80.6 \%$ untuk pupuk Borat. Hasil tersebut masih dapat ditingkatkan apabila area yang akan dipupuk terjaga kebersihan dan sanitasinya. Karena masih banyak area di perkebunan kelapa sawit ini memiliki gulma dan kacangan yang terlalu lebat sehingga mengganggu dan mempengaruhi hasil taburan pupuk. Selain itu masih banyak piringan yang kurang bersih dan kurang memenuhi standar diameter piringan yaitu $2.0 \mathrm{~m}$ sehingga hasil taburan para penabur kurang maksimal. 
Bul. Agrohorti 3 (2) : 221 - 231 (2015)

Korelasi antara Pemupukan dengan Produksi Tandan Buah Segar

Pemupukan bermanfaat untuk melengkapi persediaan unsur hara di dalam tanah sehingga kebutuhan tanaman terpenuhi dan mencapai produksi maksimal. Rencana produksi TBS optimal dengan kualitas minyak yang baik merupakan tujuan dari pemupukan pada tanaman kelapa sawit. Pupuk menggantikan unsur hara yang hilang karena pencucian dan terangkut melalui produk yang dihasilkan (Pahan, 2006). Realisasi pemupukan dan produksi TBS di perkebunan kelapa sawit ini selama enam tahun terakhir disajikan dalam tabel 7.

Tabel 7. Pemupukan dan produksi TBS salah satu perkebunan kelapa sawit di Kalimantan Barat

\begin{tabular}{cccc}
\hline & Pupuk & \multicolumn{2}{c}{ Produksi TBS } \\
\hline Tahun & Jumlah (Ton) & Tahun & Jumlah (Ton) \\
2008 & 3545,8 & 2009 & 71203 \\
2009 & 5138,3 & 2010 & 89282 \\
2010 & 4733,3 & 2011 & 98216 \\
2011 & 4620.9 & 2012 & 76156 \\
2012 & 5207.2 & 2013 & 94851 \\
2013 & 4565.2 & 2014 & 82120 \\
\hline
\end{tabular}

Data diatas menunjukkan hubungan antara pemupukan dan produksi TBS di perkebunan selama enam tahun terakhir. Tahun realisasi pemupukan dibuat berbeda dengan tahun produksi, hal ini dilakukan karena awal tahun fiskal di perkebunan ini adalah bulan Juni dan akhir tahun bulan Mei, sehingga pemupukan yang dilakukan pada tahun ini akan terlihat hasilnya atau dipanen pada tahun depan. Dari data diatas didapatkan nilai p-value sebesar 0.071 dan nilai korelasinya sebesar 0.774. Pada taraf $10 \%$ dapat dikatakan bahwa jumlah pupuk yang diberikan dalam setahun berpengaruh nyata terhadap produksi tandan buah segar kelapa sawit, dan memiliki korelasi yang positif, berarti semakin banyak pupuk yang diberikan maka produksi TBS juga akan meningkat. Faktor-faktor yang mempengaruhi produksi TBS kelapa sawit dalam satu tahun selain pupuk anorganik yaitu pemberian pupuk organik, curah hujan, dan ketersediaan tenaga kerja.

Tabel 8. Prestasi kerja karyawan penabur

\begin{tabular}{|c|c|c|c|c|c|c|c|c|}
\hline \multirow{3}{*}{ Tanggal } & \multirow{3}{*}{ Pupuk } & \multirow{3}{*}{$\begin{array}{l}\text { Luas } \\
\text { (Ha) }\end{array}$} & \multirow{3}{*}{$\begin{array}{c}\text { Jumlah Pupuk } \\
(\mathrm{Kg})\end{array}$} & \multirow{3}{*}{ Jumlah HK } & \multicolumn{4}{|c|}{ Output } \\
\hline & & & & & \multicolumn{2}{|c|}{ Luasan $(\mathrm{Ha} / \mathrm{HK})$} & \multicolumn{2}{|c|}{ Beban $(\mathrm{Kg} / \mathrm{HK})$} \\
\hline & & & & & Standar & Karyawan & Standar & Karyawan \\
\hline $15 / 04 / 2014$ & Urea & 41.87 & 7500 & 15 & 2.5 & 2.79 & 500 & 500.00 \\
\hline $17 / 04 / 2014$ & Urea & 46.6 & 7500 & 15 & 2.5 & 3.11 & 500 & 500.00 \\
\hline 02/05/2014 & Urea & 55.19 & 7550 & 15 & 2.5 & 3.68 & 500 & 503.33 \\
\hline 03/05/2014 & Urea & 54.08 & 8250 & 15 & 2.5 & 3.61 & 500 & 550.00 \\
\hline $19 / 05 / 2014$ & Urea & 54.49 & 8250 & 15 & 2.5 & 3.63 & 500 & 550.00 \\
\hline Rata-rata : & & 50.45 & 7810 & 15 & & 3.36 & 500 & 520.67 \\
\hline $24 / 04 / 2014$ & MOP & 56.77 & 7900 & 15 & 2.5 & 3.78 & 500 & 526.67 \\
\hline 28/04/2014 & MOP & 59.69 & 7950 & 15 & 2.5 & 3.98 & 500 & 530.00 \\
\hline 05/05/2014 & MOP & 48.58 & 7500 & 15 & 2.5 & 3.24 & 500 & 500.00 \\
\hline 20/05/2014 & MOP & 54.49 & 8000 & 15 & 2.5 & 3.63 & 500 & 533.33 \\
\hline $21 / 05 / 2014$ & MOP & 50.07 & 8000 & 15 & 2.5 & 3.34 & 500 & 533.33 \\
\hline Rata-rata : & & 53.92 & 7870 & 15 & & 3.59 & 500 & 524.67 \\
\hline
\end{tabular}


Poeloengan dan Erningpraja (1994) menyatakan bahwa keberhasilan suatu usaha perkebunan kelapa sawit tidak terlepas dari faktor efisiensi. Peningkatan efisiensi dapat ditingkatkan dengan usaha menekan biaya per satuan output serendah mungkin, tanpa mengurangi hasil maupun mutu yang dicapai. Salah satu alternatif tindakan efisisensi biaya pemupukan adalah dengan meningkatkan efektivitas pemupukan dilapangan. Efisiensi tenaga kerja di perkebunan kelapa sawit ini telah tercapai dengan jumlah tenaga kerja total termasuk staf sebanyak $504 \mathrm{hk}$ dan luas lahannya sebesar 3341.2 ha, didapatkan nilai Indeks Tenaga Kerja kebun sebesar $0.1508 \mathrm{hk} \mathrm{ha}^{-1}$. menurut Pahan (2008) ITK standar untuk perkebunan kelapa sawit adalah sebesar $0.16 \mathrm{hk} \mathrm{ha}^{-1}$.

Penentuan jumlah tenaga kerja sangat berpengaruh terhadap keefektivan dan efisiensi pemupukan. Apabila tenaga kerja yang digunakan melebihi target yang ditentukan maka akan terjadi inefisiensi tenaga kerja atau pemborosan tenaga kerja sehingga berdampak pada besarnya pemberian upah kepada karyawan. Tenaga kerja pemupuk yang digunakan di perkebunan kelapa sawit ini berjumlah 15 orang ditambah dengan tenaga bongkar muat sebanyak 4 orang. Pengawasan dilakukan oleh seorang mandor pupuk dan quality cek untuk menilai kualitas taburan dilakukan oleh asisten perawatan. Prestasi tenaga kerja penabur salah satu perkebunan kelapa sawit di Kalimantan Barat ini dapat dilihat pada Tabel 8.

Karyawan di perkebunan kelapa sawit ini telah memenuhi standar yang ditentukan kebun. Angka rata-rata prestasi kerja karyawan telah melebihi standar, untuk luasan rata-rata 3.36 ha $^{-1}$ untuk Urea dan 3.59 ha $\mathrm{hk}^{-1}$ dari standar $2.5 \mathrm{ha} \mathrm{hk}^{-1}$. Beban kerja telah melebihi dari standar kebun, yaitu $520.67 \mathrm{~kg} \mathrm{hk}^{-1}$ untuk pupuk Urea dan $524.67 \mathrm{~kg} \mathrm{hk}^{-}$ ${ }^{1}$ untuk pupuk MOP. Jika karyawan telah bekerja melebihi dari target maka karyawan akan mendapatkan premi sesuai standar perusahaan.

Tabel 9. Uji t-student prestasi kerja penabur berdasarkan klasifikasi tingkat usia

\begin{tabular}{|c|c|c|c|c|}
\hline \multirow{2}{*}{$\begin{array}{l}\text { Usia } \\
\text { (tahun) }\end{array}$} & \multirow{2}{*}{$\frac{\sum}{\text { Tenaga Kerja }}$} & \multirow{2}{*}{$\begin{array}{c}\text { rata-rata } \\
\text { Prestasi Kerja }(\mathrm{Kg})\end{array}$} & \multicolumn{2}{|c|}{ Uji t-student } \\
\hline & & & St. Deviasi & P-Value \\
\hline$\leq 35$ & 5 & 502 & 20.494 & $0.493^{a}$ \\
\hline$>35$ & 5 & 490 & 24.495 & \\
\hline
\end{tabular}

Keterangan : $1^{\text {a }}=$ angka yang diikuti dengan huruf menunjukkan bahwa hasil pengujian t-student tidak berbeda nyata pada taraf $5 \%$

Tabel diatas menunjukkan hasil bahwa usia penabur tidak berbeda nyata terhadap prestasi kerja yang dihasilkan. Hal ini disebabkan karena prestasi kerja yang didapatkan pemupuk tidak dipengaruhi oleh tingkat usia melainkan berdasarkan target yang telah ditetapkan oleh mandor. Sehingga setiap penabur harus menyelesaikan target dengan jumlah tonase yang hampir sama.

Tabel 10. Uji t-student prestasi kerja penabur berdasarkan lama bekerja

\begin{tabular}{ccccc}
\hline $\begin{array}{c}\text { Lama Bekerja } \\
\text { (tahun) }\end{array}$ & $\sum$ Tenaga Kerja & $\begin{array}{c}\text { rata-rata } \\
\text { Prestasi Kerja }(\mathrm{Kg})\end{array}$ & St. Deviasi & P-Value \\
\cline { 4 - 5 } & 5 & 494 & 19.494 & $0.621^{\mathrm{a}}$ \\
$>5$ & 5 & 500 & 24.495 & \\
\hline
\end{tabular}

Keterangan : $1^{\mathrm{a}}=$ angka yang diikuti dengan huruf menunjukkan bahwa hasil pengujian t-student tidak berbeda nyata pada taraf $5 \%$

Tabel diatas menunjukkan hasil bahwa lama bekerja penabur tidak berbeda nyata terhadap prestasi kerja yang dihasilkan. Hal ini disebabkan karena prestasi kerja yang didapatkan penabur berdasarkan target yang telah ditentukan oleh mandor dan disetujui oleh asisten. Oleh karena itu semua penabur harus menyelesaikan target tersebut dengan tonase yang hampir sama. 


\section{KESIMPULAN}

Kegiatan pemupukan di perkebunan kelapa sawit ini telah berjalan dengan baik. Kaidah tepat jenis, tepat cara, dan tepat dosis telah terpenuhi meskipun masih dapat ditingkatkan lagi pada aspek cara pemupukan dan ketepatan dosisnya. Piringan yang kurang bersih dan diameter piringan yang kurang memenuhi standar menjadi penyebab angka ketepatan cara belum mencapai 90\%, sehingga dapat ditingkatkan dengan menjaga kebersihan piringan dan diameter piringan tersebut. Takaran yang ada hanya satu macam sehingga akan mempengaruhi ketepatan dosis pada beberapa jenis pupuk, sehingga sebaiknya digunakan takaran yang standar untuk setiap macam pupuk. Sedangkan untuk waktu aplikasi belum memenuhi kaidah ketepatan waktu, karena aplikasi pupuk di perkebunan ini tergantung dari ketersediaan pupuk di gudang sehingga waktu rekomendasi dengan aplikasi dilapangan tidak sama. Jumlah pupuk yang diberikan dalam dalam setahun cenderung berpengaruh nyata terhadap produksi TBS, dan memiliki korelasi yang positif antar keduanya. Efisiensi tenaga kerja di kebun ini telah tercapai yakni dengan ITK $0.1508 \mathrm{hk} \mathrm{ha}^{-1}$.

\section{DAFTAR PUSTAKA}

Adiwiganda, R. 2007. Manajemen Tanah dan Pemupukan Kelapa Sawit. Di dalam: S. Mangoensoekarjo, editor. Manajemen Tanah dan Pemupukan Budidaya Tanaman Perkebunan. Yogyakarta (ID) : Gadjah Mada University Press

[Ditjenbun] Direktorat Jenderal Perkebunan. 2013. Statistika [Internet]. [diunduh 29Juni]. Tersedia pada www.ditjenbun.deptan.go.id

Hidayat, W. 2012. Manajemen Pemupukan pada Perkebunan Kelapa Sawit (Elaeis guineensis Jacq.) di Tambusai Estate, PT. Panca Surya Agindo, First Resources Ltd., Kabupaten Rokan Hulu, Riau. [Skripsi]. Bogor (ID) : IPB
Lubis, A.U. 2008. Kelapa Sawit (Elaeis guneensis Jacq.) di Indonesia. Medan (ID) : Pusat Penelitian Marihat Bandar Kuala Pematang Siantar

Mahyudin, S. 2011. Manajemen Pemupukan Pada Tanaman Kelapa Sawit (Elaeis guineensis Jacq.) di Kebun Buatan, PT. Inti Indosawit Subur, Pelalawan, Riau. [Skripsi]. Bogor (ID) : IPB

Npriani, L.S. 2014. Pupuk Dalam Peningkatan Produksi Tanaman. [Internet]. [diunduh 14 Oktober 2014]. Tersedia pada : www.sugeng.lecture.ub.ac.id

Pahan, I. 2006. Panduan Lengkap Kelapa Sawit. Jakarta (ID) : Penebar Swadaya

Pahan, I. 2008. Panduan Lengkap Kelapa Sawit (Manajemen Agribisnis Hulu hingga Hilir). Jakarta (ID) : Penebar Swadaya

Poeloengan, Z., Fadli, M.L.,Winarma., Rahutomo, S., Sutarta, E.S. 2003. Permasalahan pemupukan pada Perkebunan Kelapa Sawit. Prosiding Lahan dan Pemupukan Kelapa Sawit Edisi 1. Medan (ID) : 65-78

Poeloengan, Z., Erningpraja, L. 1994. Usaha-usaha Penigkatan Efisiensi Pemupukan Tanaman Kelapa Sawit. [Internet]. [diunduh 28 Juni 2014].

Sutarta, E.S., dan Winarna. 2002. Upaya Peningkatan Efsiensi dan Langkah Alternatif Pemupukan pada Tanaman Kelapa Sawit. Bulletin WARTA Pusat Penelitian Kelapa Sawit 10 (2-3) : 2332

Winarna., Darmosarkoro, W., Sutarta, E.S. 2003. Teknologi Pemupukan Kelapa Sawit. Prosiding Lahan dan Pemupukan Kelapa Sawit Edisi 1. Medan (ID) : 109-13 